\title{
NEWLY SYNTHESIZED AMANTADINE DERIVATIVE: SAFETY AND NEUROPHARMACOLOGICAL ACTIVITY
}

\author{
IVANKA STANKOVA ${ }^{1 *}$, MARIA LAZAROVA ${ }^{2}$, RADOSLAV CHAYROV $^{1}$, ANDREI \\ POPATANASOV $^{2}$, LYUBKA TANCHEVA $^{2}$, RENI KALFIN $^{2}$ \\ ${ }^{I}$ Department of Chemistry, "Neofit Rilski" South-West University, 66 Ivan Michailov Street, 2700 Blagoevgrad, Bulgaria \\ ${ }^{2}$ Institute of Neurobiology, Bulgarian Academy of Sciences, 23 Acad. G. Bonchev Street, 1113 Sofia, Bulgaria
}

*corresponding author: ivastankova@abv.bg

Manuscript received: January 2021

\begin{abstract}
The clinical use of amantadine (AMT, Am) is limited because of safety, tolerability issues, and duration of its anti-dyskinetic efficacy. Hence, the aim of this study was to synthesize new amantadine analogues as potential antiparkinsonian agents: phenylalanyl-amantadine (1), (4-F)-phenylalanyl-amantadine (2) and tyrosinyl-amantadine (Tyr-Am) (3). Tyr-Am showed the best toxicological characteristics in male ICR mice: the lowest acute toxicity (LD50 $320 \mathrm{mg} / \mathrm{kg}$ bw intraperitoneally, i.p.); $\mathrm{ED}_{50}=16 \mathrm{mg} / \mathrm{kg}$ bw, i.p.; therapeutic index $=20$; NOEL $5 \mathrm{mg} / \mathrm{kg}$ bw and threshold of acute action under $8 \mathrm{mg} / \mathrm{kg} \mathrm{bw}$, i.p. In single effective dose $(16 \mathrm{mg} / \mathrm{kg}$ bw, i.p.), Tyr-Am prolonged the hexobarbital narcosis probably due to its interaction with hexobarbital on the metabolic level. It improved significantly the neuromuscular performance in mice. Moreover Tyr-Am improved spatial memory as well as the learning and memory processes in compare to controls both after single or multiple (6 days) treatment of rodents. The effect of Tyr-Am was better than those of the referent amantadine. In conclusion the newly synthesized amantadine derivative Tyr-Am has a good neurobiological activity comparable with those of amantadine and deserves further investigations as potential antiparkinsonian agent.
\end{abstract}

\section{Rezumat}

Scopul acestui studiu a fost de a sintetiza noi analogi de amantadină ca potențiali agenți antiparkinsonieni: fenilalanilamantadină (1), (4-F)-fenilalanil-amantadină (2) şi tirozinil-amantadină (Tyr-Am) (3). Tyr-Am a prezentat cele mai bune caracteristici toxicologice la șoarecii masculi ICR: cea mai scăzută toxicitate acută (DL50 $320 \mathrm{mg} / \mathrm{kgc} \mathrm{i.p.);} \mathrm{DE} 50=16 \mathrm{mg} / \mathrm{kgc}$, i.p.; indice terapeutic = 20; NOEL $5 \mathrm{mg} / \mathrm{kgc}$ și pragul de acțiune acută sub $8 \mathrm{mg} / \mathrm{kgc}$, i.p. În doză unică (16 mg/kgc, i.p.), Tyr-Am a prelungit narcoza, probabil datorită interacțiunii sale cu hexobarbital la nivel metabolic. Tyr-Am a îmbunătăţit performanța neuromusculară, memoria spațială, precum și procesele de învățare și memorie, în comparație cu martorul, atât în tratamentulul unic cât și repetat (6 zile). În concluzie, derivatul de amantadină nou sintetizat (Tyr-Am) are o activitate neurobiologică superioară față de cea a amantadinei şi necesită investigații suplimentare, ca potenţial agent antiparkinsonian.

Keywords: new amantadine derivative, tyrosine, safety, neuropharmacological activity

\section{Introduction}

Levodopa currently is considered to be the gold standard in treatment of Parkinson's disease (PD). However, long term treatment with levodopa is complicated by motor fluctuations and dyskinesia [46] in patients and abnormal involuntary movements in the unilateral 6-hydroxydopamine (6-OHDA)-treated rats, an animal model of PD. Dopamine (DA) receptor upregulation and dysregulation of DA transmission is generally accepted for a cause of this side effects $[31,34]$. Pharmacotherapies for motor fluctuations and dyskinesia initially targeted the glutamatergic N-methylD-aspartate (NMDA) receptor [3, 6] based on a hypothesis of over-activity of glutamatergic corticostriatal projections onto medium spiny neurons forming the direct pathway.

Amantadine (Am) is weak non-competitive NMDA receptor antagonist approved for management of Parkinson's disease. It improves all clinical symptoms in patients suffer from $\mathrm{PD}$, but mainly used for treatment of L-DOPA induced dyskinesia [23, 37]. Anti-dyskinetic effect of amantadine have been documented in clinical trials $[10,12,16,41]$, but evidences exist that this effect is only partially dependent on NMDA antagonism [38]. The clinical use of amantadine is limited because of: concerns regarding its safety and tolerability issues, short duration of its anti-dyskinetic efficacy; not all patients are responsive to this treatment $[8,48]$.

These issues urged us to search for compounds that can replace levodopa and improve the efficacy of amantadine in the treatment of Parkinson's disease.

It is known that some adamantane derivatives that use moieties with high similarity to some of the metabolites from the dopamine pathway can have good antiparkinsonian effects as dopamantine, bemantan etc. $[1,43]$. Our motivation for the design of the tested compounds is that amino acid tyrosine and phenyl- 
FARMACIA, 2021, Vol. 69, 6

alanine, as natural precursors of L-DOPA offer good possibilities for creating a biodegradable bond. Halogenated amino acids have been used in drug design for a long time, as they often improve the pharmacological and binding properties of the synthesized compounds [14]. For example, recent studies of the analgesic effects of the opioid octapeptidebifalin derivative AM-94, in which phenylalanine has been replaced by (4-F)-Phe-OH, appear to increase the duration of the analgesic effects of AM-94 in rats [30]. Therefore, we have also included (4-F)-Phe$\mathrm{OH}$ in one of the new compounds. The amino acids phenylalanine and tyrosine appear to play an important role in the pathophysiology of depressive disorders. They are the two initial stages in the biosynthesis of dopamine, which in turn is the metabolic precursor of noradrenaline and adrenaline [29, 32]. Tyrosine is an essential amino acid, which is the major precursor of tyrosine hydroxylase, which is the first ratelimiting step in norepinephrine (NE) synthesis [19]. Individuals with Parkinson's disease have decreased tyrosine hydroxylase (TH) enzyme activity. Decreased $\mathrm{TH}$ expression is associated with the pathogenesis of PD and is one of the early signs of PD [42, 49]. The amount of tyrosine that crosses the blood-brain barrier depends on the ratio of tyrosine and other competing amino acids. Growdon and colleagues have shown that when tyrosine is taken orally, the plasma concentration of tyrosine increases to cross the blood-brain barrier, rating its availability for catecholamine synthesis [20]. It has been suggested that tyrosine supplementation may increase norepinephrine production and minimize orthostatic hypotension in PD [7, 21]. Tyrosine accelerates catecholamine synthesis in haemorrhagic hypotensive rats. Reduced tyrosine levels are indicated after administration of L-DOPA in PD. A double-blind, placebo-controlled, randomized clinical trial to test the effect of oral supplementation of tyrosine in patients suffering from orthostatic hypotension indicates that the dosage and the obtained levels of tyrosine in plasma and brain are important determinants of its clinical effectiveness [13].

Based on these facts, we have synthesized novel amantadine analogues with aromatic amino acids (phenylalanine, 4-F-phenylalanine and tyrosine) as potential agents for the management of PD and their safety and pharmacological activity have been investigated.

\section{Materials and Methods}

\section{Chemistry}

Unless otherwise stated, the starting materials, reagents and solvents were obtained from commercial suppliers and used without further purification. Amantadine as hydrochloride salts was purchased from SigmaAldrich (USA). Tyrosine, phenylalanine, 4-F-phenylalanine were purchased from Bachem (Germany).
Analytical thin-layer chromatography (TLC) was conducted on Merck silica gel 60 F-254, with detection by UV light (254 nm) and the following mobile phases: $\mathrm{CHCl}_{3} / \mathrm{CH}_{3} \mathrm{OH}$ (95:5); $\mathrm{CHCl}_{3} / \mathrm{CH}_{3} \mathrm{OH} / \mathrm{CH}_{3} \mathrm{COOH}$ (95:5:3); $\mathrm{nBuOH} / \mathrm{CH}_{3} \mathrm{COOH} / \mathrm{H}_{2} \mathrm{O}(3: 1: 1) .{ }^{1} \mathrm{H}$ and ${ }^{13} \mathrm{C}$ spectra were recorded on BrukerAvance II+ spectrometer (14.09 T magnet), operating at $600.11 \mathrm{MHz}$. Electrospray mass spectrometry (ESI-MS) experiments were acquired on Bruker Compact QTOF-MS (Bruker Daltonics, Bremen, Germany).

Synthesis of amino acid analogues of amantadine The new analogues of amantadine with phenylalanine, 4-F-phenylalanine and tyrosine were synthesized according to the procedure described by Knorr et al. [29]. The Boc-AA (3 mmol), DIPEA (3.1 mmol) were added to a solution of TBTU $(3 \mathrm{mmol})$ in $\mathrm{CH}_{2} \mathrm{Cl}_{2}$ (15 mL). After being stirred, the mixture was treated with amantadine along with DMAP (3 mmol). This mixture was stirred at RT for $3 \mathrm{~h}$, and then evaporated to dryness. The protected groups were removed by TFA $(5 \mathrm{~mL})$ at $0^{\circ} \mathrm{C}$ for $1 \mathrm{~h}$. After that, TFA.AA-adamantane derivatives were treated with ammonia solution.

Tyrosinyl-amantadine (Tyr-Am). (Yield 59\%). ${ }^{1} \mathrm{H}-$ NMR: (DMSO-d6) $\delta$ (ppm): 0.75. (d, $J=6.7 \mathrm{~Hz}, 3 \mathrm{H}$, H-2', D2), 0.93 (d, J = 6.7 Hz, 3H, H-2', D1), 1.18 (3H, H-2', D1), 1.26 (3H, H-2', D1), 1.45 (6H, H-2', D2), 1.49 (3H, H-4b', D1), 1.57 (3H, H-4a', D1), 1.57 (3H, H-4b', D2), 1.65 (3H, H-4a', D2), 1.84 (br., 3H, H-3, D1), 1.93 (br., 3H, H-3, D2), 2.87 (m, 2H, $\left.\mathrm{CH}_{2}, \mathrm{D} 1+\mathrm{D} 2\right), 3.44$ (D1+D2), 3.93 (m, 1H, CH, D2), 3.99 (m, 1H, CH, D1), 6.69 (m, 2H, Ar, D1), 6.70 (m, 2H, Ar, D2), 7.04 (m, 2H, Ar, D1), 7.01 (m, 2H, $\mathrm{Ar}, \mathrm{D} 2), 7.78$ (d, 1H, $J=9.4 \mathrm{~Hz}, \mathrm{NH}$-amide, D2), 7.89 (d, 2H, $J=9.4 \mathrm{~Hz}, \mathrm{NH}$-amide, D1), 8.12 (br., $1 \mathrm{H}, \mathrm{NH}_{2}, \mathrm{D} 2$ ), 8.17 (br., $2 \mathrm{H}, \mathrm{NH}_{2}, \mathrm{D} 1$ ); ${ }^{13} \mathrm{C}-\mathrm{NMR}$ : (DMSO-d6) $\delta$ (ppm): $13.6\left(\mathrm{CH}_{3}, \mathrm{D} 2\right), 13.9\left(\mathrm{CH}_{3}, \mathrm{D} 1\right)$, $36.3\left(\mathrm{CH}_{2}, \mathrm{D} 1+\mathrm{D} 2\right), 37.5(\mathrm{C}-4$, amantadine, D1), 37.6 (C-4, amantadine, D2), 37.5 (C-2, amantadine, D1), $37.6(\mathrm{C}-2$, amantadine, D2), $52.7(\mathrm{CH}, \mathrm{D} 1), 52.6(\mathrm{CH}$, D1), 53.6 (CH, D1), 53.5 (CH, D1), CQau amantadine 115 (CH-Ar, D1+D2), 124.7 (Cquat, D1+D2), 130.4 (CH-Ar, D2), 130.2 (CH-Ar, D2), 156.5 (Cquat, D1), 156.4 (Cquat, D2), 167.1 (CO, D1), 167.1 (CO, D2); ESI-MS: $314[\mathrm{M}]^{+}$.

Pharmacology

Experimental animals: male ICR mice $(18-22 \mathrm{~g}, \mathrm{n}=$ 116) and male Wistar rats (180 - $220 \mathrm{~g}, \mathrm{n}=18)$ were housed three to four per cage under controlled temperature conditions and $12 \mathrm{~h} / 12 \mathrm{~h}$ clear/dark cycle, with food and water available ad libitum. All experiments have been performed according to the rules for working with small laboratory animals. The research was conducted according the current guidelines regarding the protection of animals used for scientific purposes.

Acute and prolonged safety assessments. The test substances were dissolved in $100 \%$ DMSO (stock 
solution). All other dilutions were made with $\mathrm{dH}_{2} \mathrm{O}$. The compounds were injected intraperitoneally (i.p.) in increasing doses to reach lethal exit, according to the method of Prozorovski [40]. The main acute toxicity parameters determined were: acute action threshold $\left(\operatorname{Lim}_{\mathrm{ac}}\right)$, No Observed Effect Level (NOEL), lethal dose $50\left(\mathrm{LD}_{50}\right)$ and effective dose $50\left(\mathrm{ED}_{50}\right)$ [45]. Animal lethality was reported on a daily basis. All mice (dead and survived after day 7) were subjected to pathological anatomical examination. Observed parameters of safety. Each animal was continuously monitored for signs of intoxication: general condition, behavioural change, intensity and nature of locomotor activity, presence and nature of seizures, movement coordination, skeletal muscle tone, response to tactile, sound and light stimuli, frequency and breathing depth, skin and hair condition, tail position, faecal volume and consistency, frequency and colour of urine. Prolonged safety was monitored for 7 days.

Hexobarbital narcosis. Hexobarbital (HB) is a model substrate used for prediction of the impact of xenobiotics on hepatic cytochrome P-450 monooxigenase activity. HB (50 mg/kg bw), was injected i.p. in mice one hour after the administration of the new compound in effective dose. Mice were placed on a warmed $\left(37^{\circ} \mathrm{C}\right)$ pad and the duration of the righting reflex loss was measured (in minutes) in compare to controls treated only with HB in the same dose [47].

Behavioural assessments

For the determination of the neuropharmacology activity of the newly synthesized amantadine analogues, a set of behavioural tests was applied.

Step through test. This test creates a conditioned reflex of avoidance through negative reinforcement (electricity) according to Jarvik and Kopp [26]. The apparatus consists of two separate chambers: illuminated and dark one. The floor consists of steel grids for delivering electric shocks with $1 \mathrm{~mA}$ current and 1 second duration. Acquisition phase: mice and rats were individually placed on a platform in the illuminated chamber, taking into account the time that they enter in the dark chamber (Initial latency (IL)). When the animal entered into the dark chamber with the four paws, electrical shock was given for 1 - 2 seconds and then the rodent was removed from the apparatus. Test phase: the interval between the placement in the illuminated chamber and the entry into the dark chamber step-through latency (STL) time was measured.

Rotarod test. This test was used for evaluating the changes in the animals' motor coordination. Each animal was placed on a gyratory $(7 \mathrm{rpm} / \mathrm{min})$ and the time of falls (period of observation $3 \mathrm{~min}$ ) was determined according to Dunham and Miya [15].

Hole-board test. This test was used for evaluating the changes in the exploratory activity of the animals $[17,40]$. According to this test [4], the mouse was placed on a platform $(50 \mathrm{~cm} \times 50 \mathrm{~cm})$ with 16 symmetrically arranged round holes with a diameter of $3 \mathrm{~cm}$. The number of the head deeping in to the holes was counted for a period of 3 minutes.

Statistical analysis

The results were expressed as means \pm SEM. Data were analysed by Student's $t$-test for the comparison between two groups of animals. For the analysis of the experimental behavioural data, GraphPad PRISM, ver. 4.0 was applied [36]. Differences were considered significant at the level of $\mathrm{p}<0.05$.

Toxicological studies were performed using the method of Prozorovski et al. for calculation of $\mathrm{LD}_{50}$ and $\mathrm{ED}_{50}$ [39].

\section{Results and Discussion}

\section{Identification of amantadine analogues}

Based on the clinical studies described [13], we have created hybrid molecules containing amantadine and the precursors of L-DOPA - tyrosine and phenylalanyl, and (4-F)-phenylalanine as a phenylalanyl antagonist. To conform to these structural prerequisites, we conjugated the aromatic amino acids, via their carboxylic acid, to amantadine through the amidic bonds. The three synthesized amantadine analogues were identified through the NMR spectra which consisted of peaks derived both from the amino acid scaffold and the amantadine part as listed below (Figure 1).

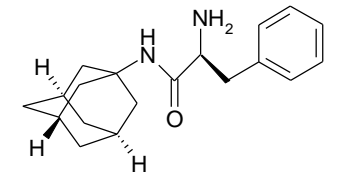

phenylalanyl-amantadine (1)

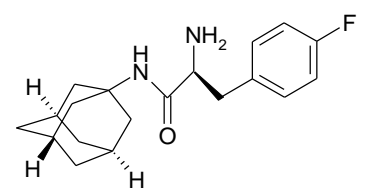

(4-F)-phenylalanyl-amantadine (2)

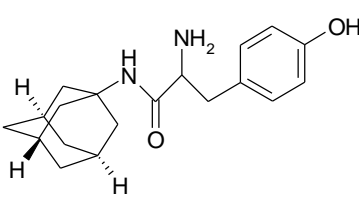

tyrosinyl-amantadine (Tyr-Am) (3)

Figure 1.

Chemical structures of amino acids analogues of amantadine

All three newly synthesized amantadine analogues: phenylalanyl-amantadine (1), (4-F)-phenylalanylamantadine (2) and tyrosinyl-amantadine (Tyr-Am) (3) were dissolved in DMSO to study their safety. Two amantadine derivatives with substituted phenyl- alanine (phenylalanine and 4-F-phenylalanine) were poorly soluble and highly toxic and we have eliminated them from further investigations.

Tyrosinyl-amantadine expressed good solubility, moderate safety and a high therapeutic index, hence it 
was the compound chosen for the subsequent safetybiochemical and neuropharmacological studies.

Safety assessments

At the first hour of treatment, the animals were severely depressed, in "frozen" posture, unstable movements, with irregular gait, lack of reaction even when touched, lethargic, gathering in groups, avoid eating. When treated with high doses, after $10-15$ minutes were observed clonic seizures with throw and tremor. Additionally Straub's phenomenon with a tail lift occurred, perhaps due to sphincter spasm, also taw of a back paws, lack of vocalizations, difficulty in breathing and cyanosis. Mice who survived, recovered almost completely within 2 hours after amantadine analogue injection.

Administered intraperitoneally at doses below 150 $\mathrm{mg} / \mathrm{kg}$ bw in mice, the Tyr-Am did not cause apparent symptoms of intoxication.

We estimated that $\mathrm{LD}_{50}$ of Tyr-Am is $320 \mathrm{mg} / \mathrm{kg}$ bw i.p.; $\mathrm{ED}_{50}$ is $16 \mathrm{mg} / \mathrm{kg}$ bw i.p.; therapeutic index is 20; NOEL is $5 \mathrm{mg} / \mathrm{kg}$ bw, threshold of acute action is under $8 \mathrm{mg} / \mathrm{kg}$ bw i.p.

On the $7^{\text {th }}$ day, we did not observe any significant changes in the animal behaviour and in food and water intake. The dissection of the animals at 24, 48 hour and day 6 showed some slight changes in the appearance of the liver (rare small spots in some hepatic tissues), but there were no changes in the lungs and other internal organs.

Effect of single effective dose Tyr-Am on duration of hexobarbital narcosis

Model substrate of hepatic cytochrome P-450 monooxygenases Hexobarbital (50 mg/kg bw, i.p.) caused narcosis for about $30 \mathrm{~min}$ in control mice. Tyr-Am in single effective dose $(16 \mathrm{mg} / \mathrm{kg}$ bw, i.p.) significantly prolonged hexobarbital narcosis (by 60\%) (Figure 2).

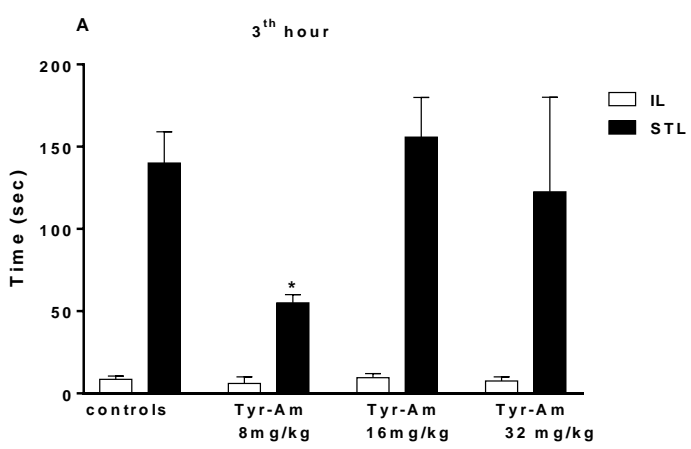

Hexobarbital sleeping time

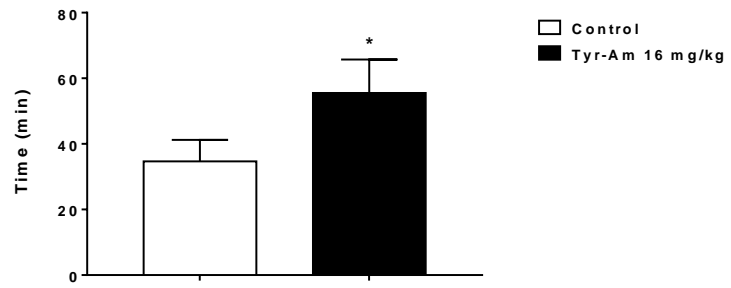

Figure 2.

Effects of Tyr-Am (16 mg/kg bw, i.p.) on hexobarbital-induced (50 mg/kg bw i.p.) narcosis Data are expressed as mean \pm SEM from 6 animals per group; $(*) \mathrm{p}<0.05 v s$. control; (Student's $t$-test)

\section{Behavioural assessments}

In order to determine single effective dose of the selected newly synthesized compound we used a set of appropriate behavioural tests, and the relationship between dose administration and observed response was evaluated via changes in neuromuscular coordination (rotarod test) and learning and memory processes (step through test) in experimental animals.

Effects of different single doses Tyr-Am on learning and memory performance in mice

After initial training, mice were treated with Tyr-Am in single doses $(8,16$ and $32 \mathrm{mg} / \mathrm{kg}$ bw, i.p.). The dose-effect relationship was monitored via changes in learning and memory processes of the tested animals in compare to the controls on the $3^{\text {rd }}$ hour (Figure $3 \mathrm{~A}$ ) and $24^{\text {th }}$ hour (Figure $3 \mathrm{~B}$ ). Our results showed that Tyr-Am, in dose $16 \mathrm{mg} / \mathrm{kg}$ bw, demonstrated the best memory, improving effect in behavioural tests used. It increases STL in both observed points, but it was more significant on the $24^{\text {th }}$ after treatment (by $45 \%, \mathrm{p}<0.05, \mathrm{n}=10)$. The dose $8 \mathrm{mg} / \mathrm{kg}$ bw had not significant effect on the memory on the $24^{\text {th }}$ hour and even it decreased latent time of the reaction on the $3^{\text {rd }}$ hour after the single treatment. In the highest dose (32 $\mathrm{mg} / \mathrm{kg} \mathrm{bw}$ ) Tyr-Am decreased STL (not significantly) as compare to Tyr-Am (16 mg/kg bw) and it kept it near to the control animals in both observed points.

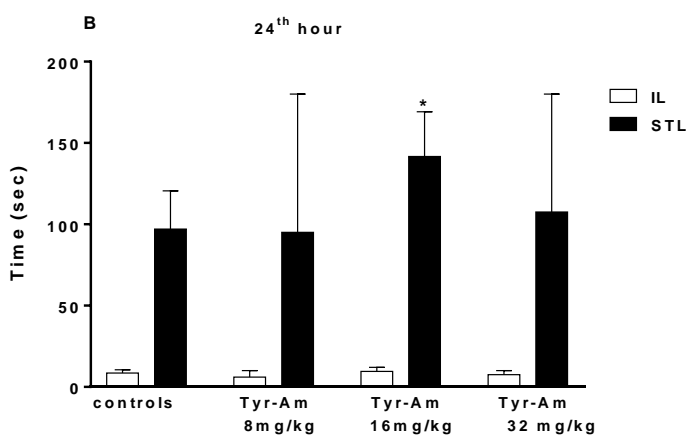

Figure 3.

Effect of Tyr-Am (8, 16 and $32 \mathrm{mg} / \mathrm{kg}$ bw, i.p.) on STL in single-trial passive avoidance test in male mice. The test was performed on the $3^{\text {rd }}$ hour (A) and on the $24^{\text {th }}$ hour (B) after single treatment

Data are expressed as means \pm SEM from 6 animals per group; $(*) \mathrm{p}<0.05$ vs. control; (Student's $t$-test) 
Effects of different single doses Tyr-Am on neuromuscular coordination in mice

The effect of Tyr-Am in dose 8, 16 and $32 \mathrm{mg} / \mathrm{kg}$ bw, i.p. on neuromuscular coordination were evaluated in mice by the rotarod test (Figure 4). The dose-effect relationship was monitored on the $3^{\text {rd }}$ hour (Figure $4 \mathrm{~A}$ ) and on the $24^{\text {th }}$ hour (Figure 4B) after acute treatment. Our results showed that Tyr-Am in dose $16 \mathrm{mg} / \mathrm{kg}$ bw demonstrated the best improving neuro-

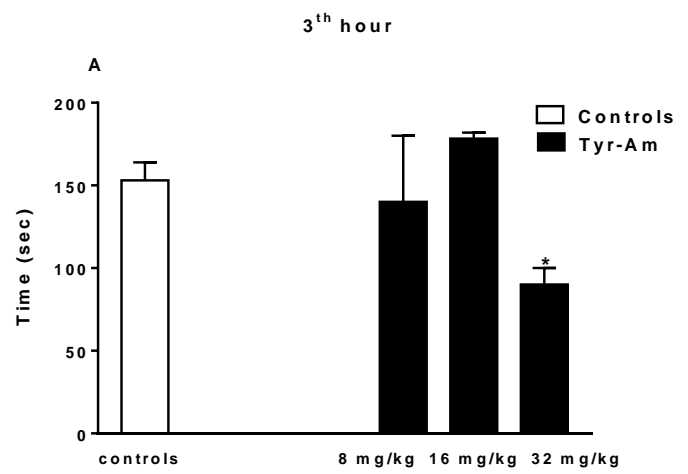

muscular coordination effect. It increased the time that animals spend on the gyratory as follows: on the $3^{\text {rd }}$ hour by $16.33 \%$ (Figure $4 \mathrm{~A}$ ) and on the $24^{\text {th }}$ hour by $39.53 \%$ (Figure $4 \mathrm{~B}$ ) in comparison to the control group. On the $3^{\text {rd }}$ hour after treatment Tyr-Am in dose $8 \mathrm{mg} / \mathrm{kg}$ bw had no significant effect and in dose 32 $\mathrm{mg} / \mathrm{kg}$ bw even reduced time spent of animal on gyratory in compare to the controls (by $41 \%$, p $<0.05$, $\mathrm{n}=10)$.

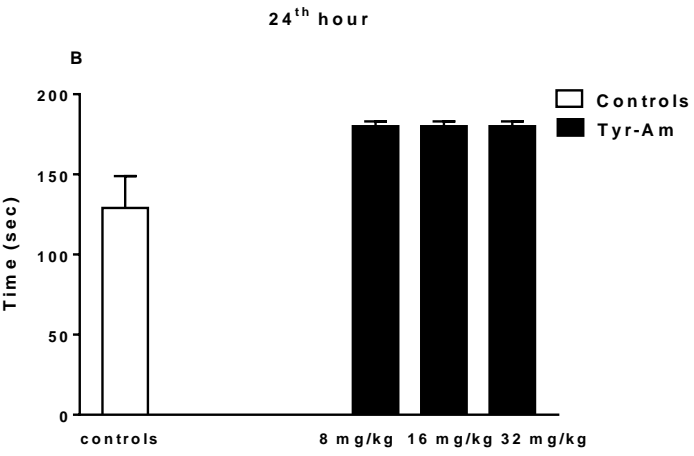

Figure 4.

Effect of Tyr-Am (8, 16 and $32 \mathrm{mg} / \mathrm{kg}$ bw, i.p.) on the time spent on spinning bar in the rotarod test. The test was performed on the $3^{\text {rd }}$ hour (A) and on the $24^{\text {th }}$ hour (B) after single treatment

Data are expressed as means \pm SEM from 6 animals per group; $(*) \mathrm{p}<0.05 v s$. control; (Student's $t$-test)

Effects of single effective dose of Tyr-Am on the exploratory activity in mice

As it is shown on Figure 5, Tyr-Am (16 mg/kg bw) significantly decreased the number of head dips by $53 \%$ for $3^{\text {rd }}$ hour $(\mathrm{p}<0.05)$ and by $45.44 \%$ for $24^{\text {th }}$ hour. This result discovered that the new compound Tyr-Am decreased exploratory activity and facilitated processes of habituation in mice.

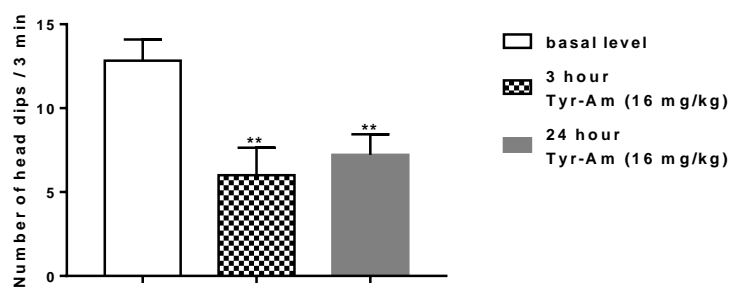

Figure 5.

Effects of Tyr-Am $(16 \mathrm{mg} / \mathrm{kg} \mathrm{bw})$ on the number of head dips in hole board test, observed for $3 \mathrm{~min}$. The test was performed on the $3^{\text {rd }}$ and $24^{\text {th }}$ hour after single treatment

Data are expressed as means \pm SEM from 6 animals per group; $(*) \mathrm{p}<0.01 v s$. basal level; (Student's $t$-test)

Effects of multiple treatment with Tyr-Am in rats The effect of Tyr-Am (16 mg/kg bw) on the learning and memory performance in passive avoidance test in rats after 6 days treatments is represented in Figure 6. The test was performed on the $24^{\text {th }}$ and on the $7^{\text {th }}$ day after daily treatment. Amantadine $(40 \mathrm{mg} / \mathrm{kg}$ bw, i.p.) was used as a referent. Our results showed that on the $24^{\text {th }}$ hour after first treatment Tyr-Am and AMT kept values as control rats in step-trough test. After repeated 6 days treatment, AMT showed insignificant tendency to decrease STL, whereas the effect of Tyr-Am demonstrated stability during the time and improved STL as compare to the controls significantly.

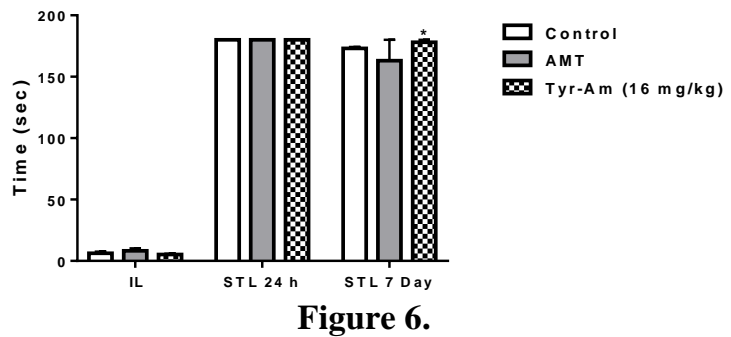

Effect of Tyr-Am (16 mg/kg bw i.p., 6 days treatment) on STL in multiple-trial passive avoidance test in male rats

Data are expressed as means \pm SEM from 6 animals per group

Three amantadine derivatives were synthesized and tested for safety and neuropharmacological activity. We found that the new compounds incorporating phenylalanyl moiety showed poor solubility and high safety probably partly due to their high hydrophobicity which may be further potentiated by the mostly aliphatic (i.e. more hydrophobic) moiety of the amantadine.

On the contrary, the new amantadine derivative with tyrosine (Tyr-Am) demonstrate good solubility. It allowed dissolution in DMSO-water mixture to 
concentrations of over $1000 \mathrm{mg} / \mathrm{L}$. This may be attributed partly to the better solubility, dipolarity/ polarizability and interactions of tyrosine with the molecules of the solvent as was found by He et al. [22].

In addition, Tyr-Am showed low toxicological parameters, which allowed to test the new compound for biological activity in experimental animals.

The results of our experiments showed that Tyr-Am significantly prolong hexobarbital narcosis. The observed pharmacological effects of the new compound was probably the result of interaction of both compounds (HB and Tyr-Am) on hepatic cytochrome P-450 level. We assume that Tyr-Am as HB probably is the substrate of hepatic P-450 linked monooxygenases and they both compete for common metabolizing enzymes. It is well known that amantadine and HB can undergo aliphatic hydroxylation and other catabolic reactions by hepatic cytochrome P-450 system [24, 27]. Micuda et al. [35] also found in in vivo study that memantine (an amantadine derivative) has inhibitory effect on some izozymes of cytochrome P-450.

It is well-known that amantadine has very successfully alleviated the motor symptoms of Parkinson's disease by blocking NMDA receptors and reducing glutamatergic transmission in the disease. In addition it stimulates secretion and blocks the reuptake of dopamine in general [11, 23, 25].

Tyrosine is part of the metabolic pathway of dopamine and has been shown to affect cognitive function in healthy animals by increasing dopamine levels $[9,18]$. Based on the fact that the new molecule is a derivative of amantadine and tyrosine, we expected a good biological activity focused on the learning and memory processes in laboratory animals. The validity of this assumption was confirmed by several classical behavioural tests on healthy mice and rats, more specifically: step through test often used to evaluate learning and memory performance, hole board test used to evaluate changes in spatial memory and exploratory activity and rotarod test which is often used to appraise the balance skills and motor coordination of animals.

Data obtained in our experiments demonstrated that Tyr-Am had a significant neurobiological activity. In single effective dose (16 mg/kg bw, i.p.) it had improved short term memory effect, manifested as increased STL in the passive avoidance test in mice. The improving learning and memory effect of Tyr-Am was established both after single treatment of mice as well as in rats after multiple 6 days treatment. Moreover, the new derivative Tyr-Am improved significantly spatial memory and orientation of animals demonstrated via decreased exploratory activity in hole board test $[2,44]$. Decreased number of head dips in Tyr-Am-treated mice in this test are result of faster habituation of treated animals in compare to controls.
To exclude possibility for some kind of sedative effect for Tyr-Am which may affect the exploratory activity of animals, we evaluated the changes in neuromuscular coordination of animals in a rotarod test. Our results pointed out that motor balance in mice after single treatment with Tyr-Am (16 mg/kg bw) was not decreased (as usually was registered after sedative drugs administration) [5, 33]. We found even the opposite effect - the neuromuscular coordination of treated animals was improved significantly in comparison to controls.

According to our experiments, Tyr-Am had better improving effect on the learning and memory than those of the referent amantadine. It allowed us to suggest that this effect probably is related partly to the new tyrosinyl moiety, which resembles mostly the biologically active part of tyrosine. Better improving memory effect of the new molecule probably is related to its amantadine structure but amino acid tyrosine also contributed for it.

\section{Conclusions}

New adamantane derivative tyrosinyl-amantadine (Tyr-Am) expressed good therapeutic index and moderate safety. It is probably metabolized by hepatic cytochrome P-450 monooxygenases. In single effective dose, $16 \mathrm{mg} / \mathrm{kg}$ bw, Tyr-Am is the neuropharmacological active compound. It ameliorated neuromuscular coordination and improved spatial memory of treated mice in comparison to controls. Tyr-Am significantly improved learning and memory of mice after single treatment as well as in rats after 6 days treatment. This effect of Tyr-Am in rats was better in compare to the reference amantadine. Our results present a promising experimental treatment of neurodegenerative disorders with Tyr-Am which deserves further investigations.

\section{Acknowledgement}

Authors are grateful to the South-West University from Bulgaria (Project RPY-A3/19) for financial support of these investigations.

\section{Conflict of interest}

The authors declare no conflict of interest.

\section{References}

1. Barnett A, Goldstein J, Taber R, Fiedler E, Pharmacology of Dopamantine and Carmantadine, 2 Potential Antiparkinson Agents. Pharmacologist, 1974; 16(2): 205.

2. Belzung $\mathrm{C}$, Measuring rodent exploratory behavior. In Techniques in the behavioral and neural sciences, 1999; 13: 738-749.

3. Blanchet PJ, Papa SM, Metman LV, Mouradian MM, Chase TN, Modulation of levodopa-induced motor response complications by NMDA antagonists in 
FARMACIA, 2021, Vol. 69, 6

Parkinson's disease. Neurosci Biobehav., 1997; 21: 447-453.

4. Boissier JR, Simon P, Lwoff JM, L'utilisation d'une réaction particulière de la souris (méthode de la planche à trous) pour l'étude des médicaments psychotropes. Therapie, 1964; 19: 571-589, (available in French).

5. Carlson JN, Haskew R, Wacker J, Maisonneuve IM, Glick SD, Jerussi TP, Sedative and anxiolytic effects of zopiclone's enantiomers and metabolite. Eur J Pharmacol., 2001; 415(2-3): 181-189.

6. Chase TN, Oh JD, Konitsiotis S, Antiparkinsonian and antidyskinetic activity of drugs targeting central glutamatergic mechanisms. J Neurol., 2000; 247(2): II36-II42.

7. Conlay LA, Maher TJ, Wurtman RJ, Tyrosine accelerates catecholamine synthesis in haemorrhaged hypotensive rats. Brain Res., 1985; 333(1): 81-84.

8. Crosby NJ, Deane KHO, Clarke CE, Amantadine for dyskinesia in Parkinson's disease. Cochrane Database Syst Rev., 2003; 2: CD003467: 1-14.

9. Cuche JL, Prinseau J, Selz F, Ruget G, Tual JL, Reingeissen L, Devoisin M, Bagin A, Guedon J, Fritel $\mathrm{D}$, Oral load of tyrosine or L-dopa and plasma levels of free and sulfoconjugated catecholamines in healthy men. Hypertension, 1985; 7(1): 81-89.

10. Da Silva-Júnior FP, Braga-Neto P, Monte FS, de Bruin VMS, Amantadine reduces the duration of levodopa-induced dyskinesia: a randomized, doubleblind, placebo-controlled study. Parkinsonism Relat Disord., 2005; 11(7): 449-452.

11. Danysz W, Parsons CG, Kornhuber J, Schmidt WJ, Quack G, Aminoadamantanes as NMDA receptor antagonists and antiparkinsonian agents: preclinical studies. Neurosci Biobehav Rev., 1997; 21(4): 455-468.

12. Del Dotto P, Pavese N, Gambaccini G, Bernardini S, Metman LV, Chase TN, Bonuccelli U, Intravenous amantadine improves levadopa-induced dyskinesias: An acute double-blind placebo-controlled study. Mov Disord., 2001; 16(3): 515-520.

13. DiFrancisco-Donoghue J, Rabin E, Lamberg EM, Werner WG, Effects of Tyrosine on Parkinson's disease: A Randomized, Double-Blind, PlaceboControlled Trial. Mov Disord Clin Pract., 2014; 1(4): 348-353.

14. Dimagno SG, Sun H, The strength of weak interactions: aromatic fluorine in drug design. Curr Top Med Chem., 2006; 6(14): 1473-1482.

15. Dunham NW, Miya TS, A note on a simple apparatus for detecting neurological deficit in rats and mice. $J$ Am Pharm Assoc., 1957; 46(3): 208-209.

16. Elahi B, Phielipp N, Chen R, N-Methyl-D-Aspartate antagonists in levodopa induced dyskinesia: a metaanalysis. Can J Neurol Sci., 2012; 39(4): 465-472.

17. File SE, Factors controlling measures of anxiety and responses to novelty in the mouse. Behav Brain Res., 2001; 125(1-2): 151-157.

18. Gibson CJ, Wurtman RJ, Physiological control of brain catechol synthesis by brain tyrosine concentration. Biochem Pharmacol., 1977; 26(12): 1137-1142.

19. Glaeser BS, Melamed E, Growdon JH, Wurtman RJ, Elevation of plasma tyrosine after a single oral dose of L-tyrosine. Life Sci., 1979; 25(3): 265-271.

20. Growdon JH, Melamed E, Logue M, Hefti F, Wurtman RJ, Effects of oral L-tyrosine administration of CSF tyrosine and homovanillic acid levels in patients with Parkinson's disease. Life Sci., 1982; 30(10): 827-832.

21. Handra C, Coman OA, Coman L, Enache T, Stoleru S, Sorescu AM, Ghiță I, Fulga I, The connection between different neurotransmitters involved in cognitive processes. Farmacia, 2019; 67(2): 193-201.

22. He Q, Cong Y, Zheng M, Farajtabar A, Zhao H, Solubility of 1-tyrosine in aqueous solutions of methanol, ethanol, n-propanol and dimethyl sulfoxide: Experimental determination and preferential solvation analysis. $J$ Chem Thermodynam., 2018; 124: 123-132.

23. Hosenbocus S, Chahal R, Amantadine: a review of use in child and adolescent psychiatry. $J$ Can Acad Child Adolesc Psychiatry, 2013; 22(1): 55-60.

24. Hrycay EG, Bandiera SM, Monooxygenase, peroxidase and peroxygenase properties and reaction mechanisms of cytochrome P450 enzymes. Adv Exp Med Biol., 2015; 851: 1-61.

25. Huber TJ, Dietrich DE, Emrich HM, Possible use of amantadine in depression. Pharmacopsychiatry, 1999; 32(2): 47-55.

26. Jarvik ME, Kopp R, An improved one-trial passive avoidance learning situation. Psychol Rep., 1967; 21(1): 221-224.

27. Kato R, Possible role of P-450 in the oxidation of drugs in liver microsomes. J Biochem., 1966; 59(6): 574-583.

28. Knorr R, Trzeciak A, Bannwarth W, Gillessen D, New coupling reagents in peptide chemistry. Tetrahedron Lett., 1989; 30(15): 1927-1930.

29. Kofler M, Schiefecker AJ, Gaasch M, SpernerUnterweger B, Fuchs D, Beer R, Ferger B, Rass V, Hackl W, Rhomberg P, Pfausler B, Thomé C, Schmutzhard E, Helbok R, A reduced concentration of brain interstitial amino acids is associated with depression in subarachnoid hemorrhage patients. Sci Rep., 2019; 9(1): 2811: 1-10.

30. Leone S, Chiavaroli A, Orlando G, Mollica A, Di Nisio C, Brunetti L, Vacca M, The analgesic activity of biphalin and its analog AM 94 in rats. Eur J Pharmacol., 2012; 685(1-3): 70-73.

31. Lindgren HS, Andersson DR, Lagerkvist S, Nissbrandt $\mathrm{H}$, Cenci MA, L-DOPA-induced dopamine efflux in the striatum and the substantia nigra in a rat model of Parkinson's disease: temporal and quantitative relationship to the expression of dyskinesia. $J$ Neurochem., 2010; 112(6): 1465-1476.

32. Lou HC, Dopamine precursors and brain function in phenylalanine hydroxylase deficiency. Acta Paediatr Suppl.. 1994; 407: 86-88.

33. McKernan RM, Rosahl TW, Reynolds DS, Sur C, Wafford KA, Atack JR, Farrar S, Myers J, Cook G, Ferris P, Garrett L, Bristow L, Marshall G, Macaulay A, Brown N, Howell O, Moore KW, Carling RW, Street LJ, Castro JL, Ragan CI, Dawson GR, Sedative but not anxiolytic properties of benzodiazepines are mediated by the GABA(A) receptor alphal subtype. Nat Neurosci., 2000; 3(6): 587-592.

34. Mela F, Marti M, Bido S, Cenci MA, Morari M, In vivo evidence for a differential contribution of striatal and nigral D1 and D2 receptors to L-DOPA induced dyskinesia and the accompanying surge of nigral amino acid levels. Neurobiol Dis., 2012; 45(1): 573-582. 
35. Micuda S, Mundlova L, Anzenbacherova E, Anzenbacher P, Chladek J, Fuksa L, Martinkova J, Inhibitory effects of memantine on human cytochrome P450 activities: prediction of in vivo drug interactions. Eur J Clin Pharmacol., 2004; 60(8): 583-589.

36. Miller JR, GraphPad Prism Ver. 4.0 Step-by-Step Examples, GraphPad Software Inc., San Diego, USA, 2003.

37. Pahwa R, Factor SA, Lyons KE, Ondo WG, Gronseth G, Bronte-Stewart H, Hallett M, Miyasaki J, Stevens J, Weiner WJ, Quality Standards Subcommittee of the American Academy of Neurology, Practice Parameter: Treatment of Parkinson disease with motor fluctuations and dyskinesia (an evidence-based review): Report of the Quality Standards Subcommittee of the American Academy of Neurology. Neurology, 2006; 66(7): 983-995.

38. Paquette MA, Martinez AA, Macheda T, Meshul CK, Johnson SW, Berger SP, Anti-dyskinetic mechanisms of amantadine and dextromethorphan in the 6OHDA rat model of Parkinson's disease: role of NMDA vs. 5-HT1A receptors. Eur J Neurosci., 2012; 36(9): 3224-3234.

39. Prozopovskii V, Prozorovskaia MP, Demchenko VM, A rapid method for the determination of the median effective dose and its errors. Farmakol Toksikol., 1978; 41(4): 497-502, (available in Russian).

40. Rogers DC, Jones DN, Nelson PR, Jones CM, Quilter CA, Robinson TL, Hagan JJ, Use of SHIRPA and discriminant analysis to characterize marked differences in the behavioural phenotype of six inbred mouse strains. Behav Brain Res., 1999; 105(2): 207-217.

41. Sawada H, Oeda T, Kuno S, Nomoto M, Yamamoto K, Yamamoto M, Hisanaga K, Amantadine Study
Group, Amantadine for dyskinesias in Parkinson's disease: a randomized controlled trial. PloS One, 2010; 5(12): e15298: 1-7.

42. Schiller A, Wevers RA, Steenbergen GSH, Blau N, Jung HH, Long-term course of L-dopa-responsive dystonia caused by tyrosine hydroxylase deficiency. Neurology, 2014; 63(8): 1524-1526.

43. Sergeevna E, Experimental study of pharmacokinetics of the antiparkinsonian drug himantan. Institute of Pharmacology, Russian Academy of Medical Sciences, 2003

44. Sharma S, Rakoczy S, Brown-Borg H, Assessment of spatial memory in mice. Life Sci., 2010; 87(17-18): 521-536.

45. Soiefer AI, Rauckman EJ, Toxicity Associated with Single Chemical Exposures. In Toxicology testing handbook: principles, applications, and data interpretation, 2001; 19-33.

46. Suh DC, Pahwa R, Mallya U, Treatment patterns and associated costs with Parkinson's disease levodopa induced dyskinesia. J Neurol Sci., 2012; 319(1-2): 24-31.

47. Vogel, HG, Vogel, WH, Psychotropic and neurotropic activity. In Drug Discovery and Evaluation, 1997; 204-316.

48. Wolf E, Seppi K, Katzenschlager R, Hochschorner G, Ransmayr G, Schwingenschuh P, Ott E, Kloiber I, Haubenberger D, Auff E, Poewe W, Long-term antidyskinetic efficacy of amantadine in Parkinson's disease. Mov Disord., 2010; 25(10): 1357-1363.

49. Zhu Y, Zhang J, Zeng Y, Overview of tyrosine hydroxylase in Parkinson's disease. CNS Neurol Disord Drug Targets, 2012; 11(4): 350-358. 